Article

\title{
Religious Beliefs and Environmental Behaviors in China
}

\author{
Yu Yang ${ }^{1, *}$ and Shizhi Huang ${ }^{2}$ \\ 1 Department of Public Administration and Moral Development Institute, Southeast University, \\ Nanjing 210096, China \\ 2 School of Public Administration, Hohai University, Nanjing 210098, China; yzfls_1@163.com \\ * Correspondence: yangyu.seu@gmail.com
}

Received: 3 January 2018; Accepted: 5 March 2018; Published: 7 March 2018

\begin{abstract}
The role of religion in the environment has yet to be empirically investigated in the country with the largest atheist population across the globe. Using data from the Chinese General Social Survey 2013, we examined the effects of religious beliefs on environmental behaviors in China. Dependent variables of private and public environmental behaviors were identified by factor analysis. The estimation revealed a contradictory result that most religious beliefs had negative effects on private environmental behaviors while having positive effects on public environmental behaviors. The findings suggest a religion-politics interactive mechanism to enhance pro-environmental behavior in China.
\end{abstract}

Keywords: private and public environmental behaviors; Chinese religions; ecological civilization; government

\section{Introduction}

Scholarly interest in studying the role of religion in the environment has received substantial attention for the past half-century. Since historian Lynn White (1967) argued that Judeo-Christianity with a domination ethic over nature had caused the ecological crisis, the consequences of the interactions between religions and the environment have been debated quite extensively in the literature (Berry 2013). With different perspectives and technical details as well as the multidimensional nature of environmental attitudes and actions, researchers have stimulated divergent results. Some researchers have provided empirical support for White's argument (Dunlap and Van Liere 1984; Eckberg and Blocker 1989; Sherkat and Ellison 2007), while others held evidence with contrasting results (Boyd 1999; Shibley and Wiggins 1997). Disparate effects were detected and given varied measures and data sets. For example, Greeley (1993) found that a willingness for environmental spending was negatively correlated with biblical literalism, but positively with being Catholic. Similarly, Hayes and Marangudakis (2000) employed a cross-country survey and suggested significant inter-denominational and intra-denominational differences within the Christian tradition in environmental attitudes. Clements et al. (2014) rejected the "greening of Christianity" view by discovering lower levels of environmental concern among Christians, and found that religiosity related positively only to pro-environmental behaviors rather than pro-environmental attitudes or beliefs. A recent typical case is the role of Evangelical Christianity in shaping climate change denial in the US context. National survey data has shown more skepticism toward climate change as well as the potential influence on policy makers associated with Evangelical Protestants (Ecklund et al. 2017).

In China, numerous studies on religion and the environment can also be discovered. Research has focused on ecological visions of specific religions, e.g., Confucianism or Neo-Confucianism (Tucker and Berthrong 1998; Tu 2001), Buddhism (Cooper and James 2005), Daoism (Girardot et al. 2001; Miller 2017), and have found their promising contributions to environmental 
attitudes. Religions are treated as a source of human values, and thus have a remarkable impact in the standards or criteria of behavioral decisions, especially regarding the environment (Stark and Finke 2000; Roccas 2005). Unlike the controversy in the Western world, in summary, explorations on the traditional wisdom of Chinese religions have mostly obtained affirmative views in academia, and consensus achieved that an eco-friendly worldview is the mainstream in China's religions (Jenkins 2002; Snyder 2006; Ching 1993). Despite plentiful discussion on the role of faith in the environment, empirical evidence still lacks. Though some case studies (Johnson 2017; Woodhouse et al. 2015; Liu et al. 2002), and research on religions and business environmental ethics (Du et al. 2014; Cui et al. 2015; Xing and Starik 2017) are emerging, a systematic statistical test on the actual effects of religious beliefs on environmental behaviors has rarely been launched at the individual level. We believe the interplay of religion and environment in China particularly deserves a thorough empirical investigation. The basic logic in connections between religion and the environment is that a religion spreads shared values through its principles, e.g., environmental awareness, and then its believers adapt their environmental behaviors accordingly. The current literature has fully covered the characteristics and potentials (mostly positive) of religions, however, the influences of religious affiliations on each believer or community's actions may not have been taken into account. To fill the missing link, a statistical analysis based on large-scale surveys is necessary.

Empirical research in the context of China is not a simple duplication using another data source. China has the largest irreligious population in the world. The country is governed by the Communist Party of China (CPC), an atheist institution. The CPC is the world's second largest political party, with nearly 90 million members by the end of 2016, that are prohibited from religious beliefs (People's Daily 2016). Non-CPC members also receive ideology education from an early age as primary and middle school students, joining the CPC's affiliate organizations, the Young Pioneers and the Communist Youth League (Xie et al. 2017). As a result, though religious freedom is protected by the Constitution, China is the least religious country. Only $14 \%$ are religious (as counted by WIN-Gallup International (2012)), and the proportion is lower in domestic statistics, e.g., $10 \%$ by the Chinese Family Panel Studies (CFPS 2012). In contrast, the global average level of religious people is 59\% (WIN-Gallup International 2012), and only Christians cover three-quarters of the population in North America and Europe (Pew Research Center 2012). Therefore, the special development situation for religions in China has already provided an unusual study target.

Interestingly, religions are officially encouraged as an effective approach to promoting a pro-environmental society. The "ecological civilization" concept, initiated at the 17th National Congress of the Communist Party of China (CPC) in 2007, has been widely spread nationwide and worldwide (Pan 2016). The new development paradigm not only integrates the transition to a greener economic growth, but also people's awareness and behaviors towards sustainability. To expand the publicity, education, and practices in the realization of ecological civilization, the function of religion has been greatly valued. A typical example is from Yue Pan, the senior deputy minister of China's Ministry of Environmental Protection from 2003 to 2016, who suggested that traditional Chinese religions serve as a powerful way to tackle China's environmental problems (Pan 2010). The State Administration for Religious Affairs (SARA) of China proposed the concept of an "ecological temple" that should play a positive role in ecological protection and education (SARA 2014). On the other hand, the religious community has responded actively. For instance, the Chinese Taoist Association (2009) published an Eight-Year (2010-2017) Planning for Environmental Protection (Chinese Taoist Association 2009) that included a cooperation framework with government environmental protection institutions as well as some international organizations including the Alliance of Religion and Conservation (ARC) and the United Nations Development Program (UNDP).

The coexistence of an atheist educational system and religious participation in environmental protection in China has created a unique and fascinating analysis object in this research field. This study may contribute to the literature, therefore, not only with a new empirical evidence, but also with a special practical case. As for the research question in this article on how religious 
beliefs affect environmental behaviors in China, enlightened by the mainstream viewpoints from theoretical perspectives, as well as the active commitment by the political community, it is preliminarily hypothesized that religious beliefs have a positive influence on environmental behaviors.

\section{Data and Measures}

\subsection{Data}

We used data from the 2013 version of the Chinese General Social Survey (CGSS 2013). The CGSS project has been a member (on behalf of Mainland China) of the International Social Survey Program (ISSP) since 2007, and has committed the Religion module of ISSP by 2013. In this study, we chose the CGSS 2013, its latest open database with better data quality and availability regarding environmental issues. Since the "ecological civilization" was formally developed into the primary discourse and a fundamental national strategy in late 2012, the examination on the social responses concerning the environment is more meaningful. The original sample size of CGSS 2013 was 11,438. The number of observations was reduced (due to refusing to answer, no opinion, recording error or contradiction) to 11,139 after a careful check on the variables to be estimated in this study. The answer to Question A5 in the questionnaire showed that nearly 90 percent of the respondents were non-believers, i.e., atheists or agnostics. Furthermore, the share of religious believers and non-believers in CGSS 2013 showed consistency with some other popular data sets (CFPS 2012; WIN-Gallup International 2012).

The distribution of the affiliations of 1237 religious believers is listed in Table 1. Since there were 50 cases of multiple religious belonging (have two or three affiliations simultaneously), a common phenomenon in Asian religious culture (Cornille 2003; Laksana 2014), the sum of religious affiliations was 1296 (see Column 2 in the table). Table 1 shows that Buddhism, Islam, and Christianity are the most popular religions in China. The folk religion group contained numerous believers, however, their specific beliefs were quite diversified-some ethnic minority areas have particular indigenous religions, e.g., Benzhuism in the Bai ethnic group, and Bimoism in the Yi ethnic group; the worship of Mazu (a Chinese sea goddess) is popular in China's coastal regions, and the Land Temples that house the God of Earth are widespread in rural villages. Hinduism, Judaism and the other non-indigenous rare religions in China were categorized as "others".

Table 1. The Distribution of Religious Affiliations in CGSS 2013.

\begin{tabular}{ccc}
\hline Religious Affiliations & Frequency & Percent \\
\hline Buddhism & 565 & 5.07 \\
Islam & 237 & 2.13 \\
Christianity & 191 & 1.71 \\
Catholicism & 38 & 0.34 \\
Daoism & 37 & 0.33 \\
Folk Religions & 211 & 1.89 \\
Others & 17 & 0.15 \\
Non-believers & $\mathbf{9 9 0 2}$ & $\mathbf{8 8 . 8 9}$ \\
\hline
\end{tabular}

\subsection{Dependent Variables}

We constructed the dependent variables, environmental behaviors, from Question B22 titled "Have you been involved in any of the following activities in the recent year?" in the CGSS 2013 questionnaire. A series of 10 items regarding environmental behaviors was designed: (1) waste sorting; (2) discuss environmental topics with families and friends; (3) bring own basket or bag when shopping; (4) reuse plastic bags; (5) donate to environmental protection; (6) show interests in the environmental information from radio, television or newspapers; (7) participate in environmental activities organized by the government; (8) participate in environmental activities organized by non-governmental organizations; (9) plant and maintain trees or green spaces with own expense; and 
(10) participate in complaints and appeals of environmental issues. For each pro-environmental activity, respondents were required to choose among options of never/occasionally/frequently based on their actual experiences, then we gave scores of never $=1$, occasionally $=2$, and frequently $=3$, respectively.

The CGSS 2013 questionnaire has relatively more items on environmental behaviors when compared with other literature (Greeley 1993; Ohtomo and Ohnuma 2014) as well as to the International Social Survey Program, which had only two environmental behavior questions in its 2000 version and six questions in 2010 version (ISSP Research Group 2003, 2012). Nevertheless, to avoid the potential trouble brought by those highly correlated variables, it was necessary to employ factor analysis to extract factors. As seen from Table 2, the results of the rotated factor loadings suggested two components highlighted in bold. According to the meaning of each environmental behavior (EB), and adopting a similar approach used in previous studies (Hadler and Haller 2011; Sherkat and Ellison 2007), we redefined the two factors as: private environmental behaviors (EB 1,2,3,4, and 6), and public environmental behaviors (EB 5,7,8,9, and 10). The "private" behaviors refer to personal activities that could be done by a single person or within the family unit, while the "public" behaviors require the arrangement by organizations or even political forces to achieve.

The numerical scores of the two dependent variables were finally obtained after normalization ranging from 0 to 100 . The scale reliability coefficient (Cronbach's alpha) was 0.75 . The private environmental behavior scores (mean $=49.87$, S.D. $=20.35$ ) were markedly higher than the public environmental behavior scores (mean $=14.85$, S.D. $=14.86$ ). Moreover, the scores could preliminarily reveal the disparities between religious believers and non-believers. The religious believers were slightly more active in public environmental behaviors (mean $=15.36$, S.D. $=15.85$ ) when compared with non-believers $($ mean $=14.79$, S.D. $=14.73)$, while less active in private environmental behaviors $($ mean $=48.80$, S.D. $=18.61)$ than non-believers $($ mean $=50.00$, S.D. $=20.55)$.

Table 2. Rotated Factor Loadings.

\begin{tabular}{ccc}
\hline Variables & Factor $\mathbf{1}$ & Factor $\mathbf{2}$ \\
\hline EB 1 & 0.3056 & $\mathbf{0 . 5 2 8 9}$ \\
EB 2 & 0.3503 & $\mathbf{0 . 5 7 7 4}$ \\
EB 3 & -0.0316 & $\mathbf{0 . 7 5 7 3}$ \\
EB 4 & -0.1173 & $\mathbf{0 . 7 3 5 6}$ \\
EB 5 & $\mathbf{0 . 6 3 2 4}$ & 0.2125 \\
EB 6 & 0.4284 & $\mathbf{0 . 5 0 5 7}$ \\
EB 7 & $\mathbf{0 . 7 2 7 8}$ & 0.2770 \\
EB 8 & $\mathbf{0 . 7 8 6 0}$ & 0.1692 \\
EB 9 & $\mathbf{0 . 6 1 5 1}$ & -0.0636 \\
EB 10 & $\mathbf{0 . 6 9 3 8}$ & -0.0026 \\
\hline
\end{tabular}

EB = environmental behavior. Number of observations $=11,139$. Method: Principal-Component Factors. Rotation: Orthogonal Varimax (Kaiser on). Kaiser-Meyer-Olkin measure of sampling adequacy $=0.8121$.

\subsection{Independent Variables}

The core variable of interest is religious affiliation, as summarized in Table 1. All religious affiliations except "others" were kept in our estimation models. Meanwhile, several factors were included as control variables (see Table 3 for detailed statistics). Sociodemographic variables including gender, ethnicity, education, CPC (the Communist Party of China) membership, and residency status were dummy variables. Another controlled factor was the interval variable, age, generated by the equation "2013-birth year" given that information on birth date was collected by Question A3 in the questionnaire. It was observed that the majority of religious believers were female, ethnic-Han, less educated, non-CPC members, rural residents, and 2.43 years older on average. However, within the ethnic minority groups, a relatively larger proportion were religious believers.

An additional control variable, Environmental Threats, was identified to measure the seriousness of environmental threats that had a direct and strong influence on the potential willingness of the 
participants' environmental behaviors (Chen et al. 2013; Hadler and Haller 2011). This is an index derived from Question B21 in the questionnaire. The respondents were asked about their personal judgement on local environmental risks, where 12 items were listed describing various common environmental hazards, e.g., air pollution, water pollution, desertification. A five-point scale from 'extremely serious' to 'not serious at all' was designed so that score 1 was rated as the least serious and 5 was the most serious answer. Aggregated scores for each item were normalized to generate the Environmental Threats Index that ranged from 0 to 100 (Cronbach's alpha $=0.89$ ). Individual assessments on environmental threats are supposed to be closely linked with their environmental behaviors. A higher index indicates that environmental issues are of more concern to the respondents, therefore their responsive behaviors would be more active.

Table 3. Descriptive Statistics of Control Variables.

\begin{tabular}{|c|c|c|c|c|}
\hline \multirow{2}{*}{ Variables } & \multicolumn{2}{|c|}{ Religious Believers } & \multicolumn{2}{|c|}{ Non-Believers } \\
\hline & Frequency & Percent & Frequency & Percent \\
\hline \multicolumn{5}{|l|}{ Gender } \\
\hline Male $=1$ & 502 & 40.58 & 5104 & 51.55 \\
\hline Female $=0$ & 735 & 59.42 & 4798 & 48.45 \\
\hline \multicolumn{5}{|l|}{ Ethnicity } \\
\hline Han $=1$ & 931 & 75.26 & 9277 & 93.69 \\
\hline Others $=0$ & 306 & 24.74 & 625 & 6.31 \\
\hline \multicolumn{5}{|l|}{ Education * } \\
\hline University or above $=3$ & 137 & 11.08 & 1687 & 17.04 \\
\hline High School = 2 & 194 & 15.68 & 1938 & 19.57 \\
\hline Middle School = 1 & 333 & 26.92 & 2914 & 29.43 \\
\hline Primary School or below $=0$ & 573 & 46.32 & 3363 & 33.96 \\
\hline \multicolumn{5}{|l|}{ CPC Membership } \\
\hline Yes $=1$ & 72 & 5.82 & 1059 & 10.69 \\
\hline $\mathrm{No}=0$ & 1165 & 94.18 & 8843 & 89.31 \\
\hline \multicolumn{5}{|l|}{ Residency Status } \\
\hline Urban $=1$ & 478 & 38.64 & 3998 & 40.38 \\
\hline \multirow[t]{2}{*}{ Rural $=0$} & 759 & 61.36 & 5904 & 59.62 \\
\hline & Mean & S.D. & Mean & S.D. \\
\hline Age $(\min =17, \max =97)$ & $\begin{array}{c}50.68 \\
(\min =18, \max =92)\end{array}$ & 16.73 & $\begin{array}{c}48.25 \\
(\min =17, \max =97)\end{array}$ & 16.37 \\
\hline Environmental Threats $(0-100)$ & 37.75 & 20.60 & 38.14 & 21.12 \\
\hline Observations & 1237 & & 9902 & \\
\hline
\end{tabular}

\section{Results and Discussion}

We used the ordinary least squares (OLS) regression method and generated results presented in Table 4. The estimation strategy was to include only the religious predictors first (Models 1 and 3), then add the control variables (Models 2 and 4). To preclude the potential multicollinearity, variance inflation factors (VIF) were calculated. The means of the VIF in Models 1-4 were 1.00, 1.32, 1.00, and 1.32 , respectively.

\subsection{Effects of Religions}

As seen in Table 4, the coefficients on variables of interest including Buddhism, Islam, Christianity, Catholicism, Daoism, and folk religions, were all negative in Model 1. After controlling a variety of factors that may affect environmental behaviors, the effects remain, excluding Buddhism (Model 2), while most coefficients were not statistically significant. The reason for the sign switching of Buddhism might have been caused by its sociodemographic characteristics. In our sample, Buddhists had a 
relatively higher proportion of female and educated believers than the average of the whole religious group. This pattern could be verified by another data set, the Chinese Family Panel Studies 2012, where Buddhists tend to be younger, better educated, and generally wealthy (CFPS 2012). As can be seen in the next subsection reporting the results of control variables, these sociodemographic factors are significant determinants to positive private environmental behaviors. We preliminarily assumed that these unexpected results may be linked to the personal characteristics of religious believers.

Table 4. Regression Results of Private and Public Environmental Behaviors.

\begin{tabular}{|c|c|c|c|c|}
\hline & \multicolumn{2}{|c|}{ Private Behavior } & \multicolumn{2}{|c|}{ Public Behavior } \\
\hline & Model 1 & Model 2 & Model 3 & Model 4 \\
\hline \multirow{2}{*}{ Buddhism } & -0.0500 & 0.208 & 1.553 ** & $2.581^{* * *}$ \\
\hline & $(-0.06)$ & $(0.26)$ & $(2.42)$ & $(4.23)$ \\
\hline \multirow{2}{*}{ Islam } & -1.133 & -0.699 & $-3.619^{* * *}$ & $-3.052 * * *$ \\
\hline & $(-0.85)$ & $(-0.50)$ & $(-3.72)$ & $(-2.90)$ \\
\hline \multirow{2}{*}{ Christianity } & $-3.749 * *$ & -1.455 & $-2.091 *$ & 0.425 \\
\hline & $(-2.52)$ & $(-1.08)$ & $(-1.93)$ & $(0.41)$ \\
\hline \multirow{2}{*}{ Catholicism } & -4.328 & $-5.837^{*}$ & $9.678 * * *$ & $10.10^{* * *}$ \\
\hline & $(-1.29)$ & $(-1.92)$ & $(3.97)$ & $(4.37)$ \\
\hline \multirow{2}{*}{ Daoism } & -4.826 & -3.908 & $16.95^{* * *}$ & $17.37^{* * *}$ \\
\hline & $(-1.45)$ & $(-1.30)$ & (7.02) & (7.59) \\
\hline \multirow{2}{*}{ Folk Religions } & -1.348 & -1.916 & 1.344 & 1.340 \\
\hline & $(-0.95)$ & $(-1.49)$ & $(1.30)$ & (1.37) \\
\hline \multirow{2}{*}{ Gender } & & $-4.533 * * *$ & & $1.863^{* * *}$ \\
\hline & & $(-12.63)$ & & $(6.83)$ \\
\hline \multirow{2}{*}{ Ethnicity } & & -1.118 & & -0.392 \\
\hline & & $(-1.54)$ & & $(-0.71)$ \\
\hline \multicolumn{5}{|l|}{ Education } \\
\hline \multirow{2}{*}{ Middle School } & & $4.151^{* * *}$ & & $1.049^{* * *}$ \\
\hline & & $(8.58)$ & & $(2.85)$ \\
\hline \multirow{2}{*}{ High School } & & $6.829 * * *$ & & $4.240^{* * *}$ \\
\hline & & (11.45) & & (9.36) \\
\hline \multirow{2}{*}{ University or above } & & $10.83^{* * *}$ & & $7.010^{* * *}$ \\
\hline & & (15.11) & & $(12.88)$ \\
\hline \multirow{2}{*}{ CPC Membership } & & $2.483^{* * *}$ & & $2.414^{* * *}$ \\
\hline & & (3.99) & & (5.11) \\
\hline \multirow{2}{*}{ Residency Status } & & $7.274^{* * *}$ & & $0.918^{* * *}$ \\
\hline & & $(16.89)$ & & $(2.81)$ \\
\hline \multirow{2}{*}{ Age } & & $0.0490^{* * *}$ & & $-0.0593^{* * *}$ \\
\hline & & (3.77) & & $(-6.01)$ \\
\hline \multirow{2}{*}{$\begin{array}{c}\text { Environmental } \\
\text { Threats }\end{array}$} & & $0.174^{* * *}$ & & $0.0852 * * *$ \\
\hline & & (18.69) & & (12.08) \\
\hline \multirow{2}{*}{ Constant } & $50.01 * * *$ & $36.82 * * *$ & $14.77^{* * *}$ & $10.84^{* * *}$ \\
\hline & $(245.26)$ & $(34.86)$ & (99.60) & (13.51) \\
\hline $\mathrm{N}$ & 11,139 & 11,139 & 11,139 & 11,139 \\
\hline Adj R-squared & 0.0005 & 0.1766 & 0.0081 & 0.1088 \\
\hline
\end{tabular}

$T$ statistics in parentheses; ${ }^{*} p<0.1,^{* *} p<0.05,{ }^{* * *} p<0.01$. 
As for public environmental behaviors (Models 3 and 4), the signs were positive in most religions, except for Islam. The reason for the frustrating results of Islam is associated with the sampling methods of CGSS 2013. Over half of the Muslim population in China is from Xinjiang Province (Muslim Online 2017), which was unfortunately excluded from the survey due to cost and security reasons. As for Ningxia Province, the second largest region of Muslim population (Muslim Online 2017), only 100 observations (less than one percent of the whole sample) were obtained. In most other provinces outside Xinjiang and Ningxia, the Muslim population have very low proportions that below $0.2 \%$ (Muslim Online 2017), and the majority of them are internal migrants. The scattered distribution weakens the Muslim group cohesion that makes it difficult to organize public activities, including environmental events. Due to the irregular sample pattern and absence of core regions, we do not believe that the results here could precisely reveal the actual effect of Islam in China. Some research on the largest Muslim country, Indonesia, have already confirmed a positive function from Islam (Mangunjaya 2011; Mangunjaya and McKay 2012; Saniotis 2012). After ignoring Islam, religions had positive effects on public environmental behaviors across all other affiliations, and the effects were statistically significant for three religions, i.e., Buddhism, Catholicism, and Daoism.

\subsection{Control Variables}

The factors of education, CPC membership, and Environmental Threats had significantly positive effects as expected. Since the idea of an ecological civilization has been strengthened as a morality and ideology among education institutions and government agencies (Ford and Rowe 2017; McBeath et al. 2014), more-educated people as well as government employees, especially CPC members, would have an increasing environmental awareness and improved environmental behaviors. On average, more education led to a higher level of environmental behaviors, while the effects of education were more obvious for private environmental behaviors. However, the impacts from CPC membership had no clear distinction between private and public behaviors. Environmental Threats, which is an expression of personal feelings on environmental degradation, have naturally shown more influence on private environmental behaviors.

As for the effect of residency status, it is also unchallenging to understand that people from urban areas-who face more serious pollution in their daily lives-would reflect more active behaviors than those in rural areas. In addition, more relevant effects were associated with private behaviors than public behaviors.

Determinants including gender, age and ethnicity, however, presented some disparities. Men had significantly negative attitudes towards private environmental behaviors while the case of public environmental behaviors is to the contrary. This finding was divergent with some empirical evidence from the Western world where women are more committed to environmental movements (Tindall et al. 2003; Smith 2001), while similar to a study in China finding greater "inside of the home" environmental behaviors by women (Xiao and Hong 2010). The explanation of this phenomenon might be related with the descriptions of private behaviors in the questionnaire that most items are everyday routines charged by female groups, e.g., waste sorting, reusing bags when shopping. Women tend to care more about daily resource conservation and energy efficiency, which possibly formed their environmental-friendly habits (Jiggins 1994).

In addition, an older individual performed significantly better in private environmental behaviors, but was worse in public environmental behaviors. This result indicated that younger people appeared to have more extensive participation in environmental affairs (United Nations 2004; Schusler and Krasny 2008). Compared with ethnic minority groups, ethnic-Han people showed lower scores in both private and public behaviors, however, the effects were insignificant.

\subsection{Discussion}

By joining the control variables, most of the coefficients of religious beliefs increased in both private and public environmental behaviors. We believe that the religious effects on environmental 
behaviors in China were well observed from this estimation. It demonstrates that religions have contradictory influences between private and public actions, which do not fully support the hypothesis. Therefore, further clarification for the statistical outputs are necessary to discuss.

The central issue is the dominating determinants for private environmental behaviors- the personal characteristics of believers, or the inner insights and values of religions? The vast majority of the literature theoretically supports the pro-environmental spirits in Chinese traditional religions (Yao 2014; Jenkins 2002; Snyder 2006); nevertheless, only Buddhism predicted an insignificant positive effect in our sample. The analyses on control variables have indicated strong connections between sociodemographic factors and environmental behaviors. Chinese religious believers have overall deficiency in education, residency status, and CPC membership, which may be the crucial reason for their poor performance in private environmental behaviors. A similar case was shown through indirect empirical evidence where a number of Buddhist monasteries around Chinese listed firms had a positive effect on corporate environmental responsibility (Du et al. 2014). Considering most of the listed firms are state-owned by central or local government and are located in urban areas, those features could generate interaction effects with Buddhism. As for the negative results in other religious affiliations, we also argue that the key explanation is not theoretically related to the foundation of the religious attitudes. Since these believers have even lower education levels, more rural residents and fewer CPC members than Buddhists, more personal constrains are placed upon their practical environmental behaviors. Though the sociodemographic variables have controlled some negative effects, the net effects seem to remain unchanged. The diverse and multiplex consequences suggest a further issue of balancing between environmental attitudes and practical behaviors.

Another subject worth discussing is the religious role in shaping public environmental behaviors. The CGSS 2013 survey showed scores of private environmental behaviors in China were three times higher than public behaviors. Estimations have also suggested relatively insufficient impacts on public behaviors from factors including education and residency status. Even Environmental Threats and CPC membership exerted a slight effect on private when compared with public environmental behaviors. These findings indicate a lagging stage in the development of China's public sphere. Nevertheless, the impacts from most religious affiliations have shown encouraging results regarding public environmental behaviors. For an individual, being pro-environmental religious would not definitely make one's private behaviors identical. When an individual becomes part of a certain religion, however, collective action could be motivated. Participation in temples or churches, as well as group program attendances would help in facilitating pro-environmental behaviors by establishing conducive platforms such as recycling programs and car-pooling. Meanwhile, religious resources can be used to drive cross-cultural exchange of political views and boost the process of environmental activism (Sherkat and Ellison 2007; Caputo 2009). For example, the Mochou Environmental Protection Association was founded as a Chinese environmental non-government organization by a Buddhist in 2007 (Hernández 2017). As a result of outstanding work and social contribution in water environment protection, it was awarded the "Earth Award" by China's Ministry of Environmental Protection in 2012.

Moreover, the strong involvement of the Chinese government is currently enhancing the positive benefits from religions, while supplementing the limitations of political propaganda and ideology education. A typical action is a policy jointly issued by SARA and 11 other central authorities in November 2017, that emphasized the non-profit nature of Buddhist and Taoist temples, and their roles in guiding religious people to establish pro-environmental social norms (Xinhua 2017). Religions are being expected to serve as an effective approach in attracting public attention and creating interaction opportunities for promoting environmental social responsibilities. The net effects would be convincing if the cooperation combined well with the religious world and public policy aspects.

\section{Conclusions}

As the least religious country governed by the world's largest atheist political party, empirical research on the influences from religions still lack in many fields, especially regarding environmental 
issues. This article intends to fill the lacuna by examining the interrelationships between sets of religious affiliations and two types of environmental behaviors. Our empirical findings showed a contradictory result that most religious beliefs had negative effects on private environmental behaviors, but had positive effects on public environmental behaviors. The distinction is unsurprising considering two facts: religious believers in China have the sociodemographic characteristics of less educated, more rural residents, and fewer CPC members; and the development of environmentalism in China's public sphere is still at a very early stage. The interpretation based on those evidences would lead to two conclusions. First, the personal characteristics of religious believers have constrained their environmental practices, though major religions themselves support pro-environmental traditions and values. Second, religions could undertake the role of an environmentalist guide, drawing on their faith to organize believers and influence irreligious communities. In addition, aside from traditional Chinese religions, other affiliations such as Christianity and Catholicism are also inspired to vigorously engage in public pro-environmental actions, which somewhat differs with divergent results from prior research in Western academia.

The findings from our investigation are quite encouraging and promising. The complementarity of informal religious cultures and formal governmental enforcement appears to have become a new mechanism to enhance pro-environmental behaviors in China. As criticized by scholars and the general public, China's environment deterioration over the past decades may be related to the lack of faith. Meanwhile, formal institutions such as laws and regulations have failed to achieve the desired outcomes. The ongoing pursuit of ecological civilization requires a fundamental civilizational change and deep-rooted ethics is crucial. Fortunately, religions are building the bridge between the environmental atmosphere on the macro-dimension and the environmental behaviors of the individual on the micro-dimension. Therefore, the revealed close religion-politics interaction on environmental issues could provide certain policy choices in the process of ecological civilization construction in China. An essential policy recommendation is to protect and foster positive religious activities that contain traditional pro-environmental beliefs. Meanwhile, it is necessary to offer public assistance to those religious believers of lower social and economic status to stimulate their spontaneous environmental behaviors.

Acknowledgments: This research was financially supported by the National Social Science Foundation of China (Grant No. 17BZX102). The authors would like to thank the editors and reviewers for providing valuable comments that helped us to improve the manuscript.

Author Contributions: Yu Yang designed the research, and drafted the manuscript. Shizhi Huang performed the data collection and statistical analysis. The authors jointly edited and approved the final manuscript.

Conflicts of Interest: The authors declare no conflict of interest.

\section{References}

Berry, Evan. 2013. Religious Environmentalism and Environmental Religion in America. Religion Compass 7: 454-66. [CrossRef]

Boyd, Heather Hartwig. 1999. Christianity and the Environment in the American Public. Journal for the Scientific Study of Religion 38: 36-44. [CrossRef]

Caputo, Richard K. 2009. Religious Capital and Intergenerational Transmission of Volunteering as Correlates of Civic Engagement. Nonprofit and Voluntary Sector Quarterly 38: 983-1002. [CrossRef]

Chinese Family Panel Studies (CFPS). 2012. Available online: http:/ / www.isss.pku.edu.cn/cfps/EN/Data/2012/ 244.html (accessed on 16 August 2017).

CGSS. 2013. Chinese General Social Survey (中国综合社会调查). Available online: http:/ /www.chinagss.org/ index.php?r=index/publication (accessed on 17 July 2017).

Chen, Xiaodong, M. Nils Peterson, Vanessa Hull, Chuntian Lu, Dayong Hong, and Jianguo Liu. 2013. How Perceived Exposure to Environmental Harm Influences Environmental Behavior in Urban China. Ambio 42: 52-60. [CrossRef] [PubMed] 
Chinese Taoist Association. 2009. Eight-Year (2010-2017) Planning for Environmental Protection in China (中国道 教界保护环境的八年规划 2010-2017). Available online: http:/ /www.arcworld.org/downloads/Daoist-8YPChinese.pdf (accessed on 17 November 2017).

Ching, Julia. 1993. Chinese Religions. Basingstoke and London: Macmillan.

Clements, John M., Aaron M. McCright, and Chenyang Xiao. 2014. Green Christians? An empirical Examination of Environmental Concern within the US General Public. Organization E Environment 27: 85-102. [CrossRef]

Cooper, David E., and Simon P. James. 2005. Buddhism, Virtue and Environment. Burlington: Ashgate.

Cornille, Catherine. 2003. Double Religious Belonging: Aspects and Questions. Buddhist-Christian Studies 23: 43-49. [CrossRef]

Cui, Jinhua, Hoje Jo, and Manuel G. Velasquez. 2015. The Influence of Christian Religiosity on Managerial Decisions Concerning the Environment. Journal of Business Ethics 132: 203-31. [CrossRef]

Du, Xingqiang, Wei Jian, Quan Zeng, and Yingjie Du. 2014. Corporate Environmental Responsibility in Polluting Industries: Does Religion Matter? Journal of Business Ethics 124: 485-507. [CrossRef]

Dunlap, Riley E., and Kent D. Van Liere. 1984. Commitment to the Dominant Social Paradigm and Concern for Environmental Quality. Social Science Quarterly 65: 1013-28.

Eckberg, Douglas Lee, and T. Jean Blocker. 1989. Varieties of Religious Involvement and Environmental Concerns: Testing the Lynn White Thesis. Journal for the Scientific Study of Religion 28: 509-17. [CrossRef]

Ecklund, Elaine Howard, Christopher P. Scheitle, Jared Peifer, and Daniel Bolger. 2017. Examining Links between Religion, Evolution Views, and Climate Change Skepticism. Environment and Behavior 49: 985-1006. [CrossRef]

Ford, Marcus, and Stephen Rowe. 2017. Educating for an Ecological Civilization: Interdisciplinary, Experiential, and Relational Learning. Claremont: Process Century Press.

Girardot, Norman J., James Miller, and Xiaogan Liu. 2001. Daoism and Ecology: Ways within a Cosmic Landscape. Cambridge: Harvard University Press.

Greeley, Andrew. 1993. Religion and Attitudes toward the Environment. Journal for the Scientific Study of Religion 32: 19-28. [CrossRef]

Hadler, Markus, and Max Haller. 2011. Global Activism and Nationally Driven Recycling: The Influence of World Society and National Contexts on Public and Private Environmental Behavior. International Sociology 26: 315-45. [CrossRef]

Hayes, Bernadette C., and Manussos Marangudakis. 2000. Religion and Environmental Issues within Anglo-American Democracies. Review of Religious Research 42: 159-74. [CrossRef]

Hernández, Javier C. 2017. China's Religious Revival Fuels Environmental Activism. The New York Times. Available online: https:/ / www.nytimes.com/2017/07/12/world/asia/mao-mountain-china-religion-environment. html (accessed on 17 November 2017).

ISSP Research Group. 2003. International Social Survey Programme: Environment II-ISSP 2000. Cologne: GESIS Data Archive. ZA3440 Data file Version 1.0.0. [CrossRef]

ISSP Research Group. 2012. International Social Survey Programme: Environment III-ISSP 2010. Cologne: GESIS Data Archive. ZA5500 Data file Version 2.0.0. [CrossRef]

Jenkins, T. N. 2002. Chinese Traditional Thought and Practice: Lessons for an Ecological Economics Worldview. Ecological Economics 40: 39-52. [CrossRef]

Jiggins, Janice. 1994. Changing the Boundaries: Women-Centered Perspectives on Population and the Environment. New York: Island Press.

Johnson, Ian. 2017. The Souls of China: The Return of Religion after Mao. New York: Pantheon.

Laksana, Albertus Bagus. 2014. Multiple Religious Belonging or Complex Identity? An Asian Way of Being Religious. In The Oxford Handbook of Christianity in Asia. Edited by Felix Wilfred. Oxford and New York: Oxford University Press.

Liu, Hongmao, Zaifu Xu, Youkai Xu, and Jinxiu Wang. 2002. Practice of Conserving Plant Diversity through Traditional Beliefs: A Case Study in Xishuangbanna, Southwest China. Biodiversity and Conservation 11: 705-13. [CrossRef]

Mangunjaya, Fachruddin Majeri. 2011. Developing Environmental Awareness and Conservation through Islamic Teaching. Journal of Islamic Studies 22: 36-49. [CrossRef] 
Mangunjaya, Fachruddin Majeri, and Jeanne Elizabeth McKay. 2012. Reviving an Islamic Approach for Environmental Conservation in Indonesia. Worldviews: Global Religions, Culture, and Ecology 16: 286-305. [CrossRef]

McBeath, Gerald A., Jenifer Huang McBeath, Tian Qing, and Huang Yu. 2014. Environmental Education in China. Cheltenham: Edward Elgar Publishing.

Miller, James. 2017. China's Green Religion: Daoism and the Quest for a Sustainable Future. New York: Columbia University Press.

Muslim Online. 2017. Chinese Muslim Population Census (中国穆斯林人口统计表). Available online: http: / /www.muslimwww.com/html/2017/rumen_0810/32973.html (accessed on 17 September 2017).

Ohtomo, Shoji, and Susumu Ohnuma. 2014. Psychological Interventional Approach for Reduce Resource Consumption: Reducing Plastic Bag Usage at Supermarkets. Resources, Conservation and Recycling 84: 57-65. [CrossRef]

Pan, Yue. 2010. Chinese Traditional Ecological Wisdom (中华传统的生态智慧). People's Daily Overseas Edition. Available online: http:/ / paper.people.com.cn/rmrbhwb/html/2010-11/06/content_664795.htm (accessed on 17 September 2017).

Pan, Jiahua. 2016. China's Environmental Governing and Ecological Civilization. Beijing: China Social Sciences Press. People's Daily. 2016. The Norms of Political Life in the Party under Current Conditions (关于新形势下党内政治生 活的若干准则). People's Daily. Available online: http:/ / paper.people.com.cn/rmrb/html/2016-11/03/nw. D110000renmrb_20161103_1-05.htm (accessed on 17 September 2017).

Pew Research Center. 2012. The Global Religious Landscape: Christians. Available online: http:/ /www.pewforum. org/2012/12/18/global-religious-landscape-christians / (accessed on 17 September 2017).

Roccas, Sonia. 2005. Religion and Value Systems. Journal of Social Issues 61: 747-59. [CrossRef]

Saniotis, Arthur. 2012. Muslims and Ecology: Fostering Islamic Environmental Ethics. Contemporary Islam 6: 155-71. [CrossRef]

The State Administration for Religious Affairs (SARA). 2014. Notice on Further Promoting Civilization in Burning Incense and Construction of Ecological Temple (关于进一步推动文明敬香、建设生态寺观工作的通知). Available online: http:/ / www.sara.gov.cn/old/xxgk/gsgg/58220.htm (accessed on 17 November 2017).

Schusler, Tania M., and Marianne E. Krasny. 2008. Youth Participation in Local Environmental Action: An Avenue for Science and Civic Learning? In Participation and Learning: Perspectives on Education and the Environment, Health and Sustainability. Edited by Alan Reid, Bjarne Jensen, Jutta Nikel and Venka Simovska. New York: Springer. [CrossRef]

Sherkat, Darren E., and Christopher G. Ellison. 2007. Structuring the Religion-Environment Connection: Identifying Religious Influences on Environmental Concern and Activism. Journal for the Scientific Study of Religion 46: 71-85. [CrossRef]

Shibley, Mark A., and Jonathon L. Wiggins. 1997. The Greening of Mainline American Religion: A Sociological Analysis of the Environmental Ethics of the National Religious Partnership for the Environment. Social Compass 44: 333-48. [CrossRef]

Smith, D. Clayton. 2001. Environmentalism, Feminism, and Gender. Sociological Inquiry 71: 314-34. [CrossRef]

Snyder, Samuel. 2006. Chinese Traditions and Ecology: Survey Article. Worldviews: Global Religions, Culture, and Ecology 10: 100-34. [CrossRef]

Stark, Rodney, and Roger Finke. 2000. Acts of Faith: Explaining the Human Side of Religion. Berkeley: University of California Press.

Tindall, David B., Scott Davies, and Celine Mauboules. 2003. Activism and Conservation Behavior in an Environmental Movement: The Contradictory Effects of Gender. Society E Natural Resources 16: 909-32. [CrossRef]

Tu, Weiming. 2001. The Ecological Turn in New Confucian Humanism: Implications for China and the World. Daedalus 130: 243-64.

Tucker, Mary Evelyn, and John Berthrong. 1998. Confucianism and Ecology the Interrelation of Heaven, Earth, and Humans. Cambridge: Harvard University Press.

United Nations. 2004. Youth and the Environment. In World Youth Report 2003: The Global Situation of Young People. Edited by United Nations. New York: UN.

White, Lynn. 1967. The Historical Roots of Our Ecologic Crisis. Science 55: 1203-7. [CrossRef] [PubMed] 
WIN-Gallup International. 2012. Global Index of Religiosity and Atheism. Available online: http:/ /www.wingia. com/web/files/news/14/file/14.pdf (accessed on 17 September 2017).

Woodhouse, Emily, Martin A. Mills, Philip J. K. McGowan, and E. J. Milner-Gulland. 2015. Religious Relationships with the Environment in a Tibetan Rural Community: Interactions and Contrasts with Popular Notions of Indigenous Environmentalism. Human Ecology 43: 295-307. [CrossRef] [PubMed]

Xiao, Chenyang, and Dayong Hong. 2010. Gender Differences in Environmental Behaviors in China. Population and Environment 32: 88-104. [CrossRef]

Xie, Ying, Yunping Tong, and Fenggang Yang. 2017. Does Ideological Education in China Suppress Trust in Religion and Foster Trust in Government? Religions 8: 94. [CrossRef]

Xing, Yijun, and Mark Starik. 2017. Taoist Leadership and Employee Green Behaviour: A Cultural and Philosophical Microfoundation of Sustainability. Journal of Organizational Behavior 38: 1302-19. [CrossRef]

Xinhua. 2017. China Focus: Buddhist, Taoist Temples Cautioned against Excessive Commercial Practices. Xinhua News. Available online: http://news.xinhuanet.com/english/2017-11/23/c_136774521.htm (accessed on 17 December 2017).

Yao, Xinzhong. 2014. An Eco-Ethical Interpretation of Confucian Tianren Heyi. Frontiers of Philosophy in China 9: 570-85. [CrossRef]

(C) 2018 by the authors. Licensee MDPI, Basel, Switzerland. This article is an open access article distributed under the terms and conditions of the Creative Commons Attribution (CC BY) license (http:/ / creativecommons.org/licenses/by/4.0/). 